\title{
Nueve adivinanzas de Estambul (Colección Milwitzky)
}

\author{
Samuel G. ARMISTEAD \\ University of California, Davis \\ Joseph H. SILVERMAN \\ University of California, Santa Cruz
}

Queda pendiente el problema de los orígenes de la literatura oral sefardí. Siempre se ha tendido a pensar en lo peninsular, lo medieval. En una serie de publicaciones hemos subrayado, por contraste, la importancia de lo diaspórico, de lo oriental: en el romancero, en la lírica ${ }^{1}$ y tentativamente -pues el problema resulta bastante mas difícil- en los cuentos tradicionales $^{2}$. El descubrimiento ahora de unos exiguos restos de uno

1 Lo publicado hasta circa 1980 se reúne en nuestro libro En torno al romancero sefardí (Hispanismo y balcanismo de la tradición judeo-española) (Madrid 1982).

2 Véase nuestra nota (con I. M. HASSÁN) sobre M. Atrias, «El kismet de la hija del rey», Estudios Sefardíes 1 (1978) págs. 153-160; para otra versión griega (o en todo caso balcánica, pues la raconteuse griega se la había oído a una amiga rumana), divergente sobre todo en el desenlace, véase Аввотт (1903) págs. 129135 y 347-350 (las colecciones y estudios de adivinanzas aquí referidos por el nombre del autor y la fecha de publicación se encuentran reunidos en la bibliografía al final del artículo). La variante oriental del tipo 1262 Roasting the meat (A. AARne y S. Thompson, Types of the Folktale [Helsinki 1961]) que publicamos en «Dos consejas sefardíes» (Narraciones hispanoamericanas de tradición oral [Madrid 1972] págs. 95-101) es indudablemente más cercana a la forma turca que a ninguna variante hispánica; cfr. S. WALKER y A. UYSAL, Tales Alive in Turkey (Cambridge Mass. 1960) págs. 239-241: pág. 295; y A. WESSELSKI, Der Hodscha Nasreddin, 2 vols. (Weimar 1911) vol. II págs. 112-114: pág. 212 (núm. 434). Por último, nuestra edición anotada (con R. HABOucha) «Words Worse Than Wounds: A Judeo-Spanish Versión of a Near Eastern Folktale", Fabula 23 (1982) págs. 95-98 (donde también ejemplificamos algunos refranes 
de los géneros más desatendidos de la literatura folklórica judeoespañola nos insta a fijarnos en el mismo problema respecto a las adivinanzas, sin duda alguna la oveja más negra de todos los tipos genéricos ${ }^{3}$.

Las fuentes disponibles para el estudio de la adivinanza tradicional sefardí son hoy por hoy extremadamente limitadas. Las 47 adivinanzas publicadas en 1948 por Abraham Galante constituyen el corpus más nutrido, relativamente ${ }^{4}$; la colección de indivines recogidas por Max A. Luria de la tradición de Monastir (Yugoslavia) y publicadas en 1930 integra un total de 33 textos 5; hay además la breve colección de enigmas de Turquía (de Galípoli o de Esmirna) publicada en 1945 por el rabino Menahem Azuz ${ }^{6}$ y las tres adivinanzas narrativas incluidas por David Elnecavé en su artículo «Folklore de los sefar-

tradicionales traducidos directamente del turco). Con todo, el cuento judeoespañol del león insultado, pese a su gran popularidad en las lenguas balcánicas y del Oriente próximo, tiene una contraparte muy cercana en español medieval; véase Castigos e documentos ... por el rey don Sancho IV, ed. A. REY (Bloomington Ind. 1952) cap. XXVI pág. 141. Para más sobre el orientalismo de la tradición sefardí, véase nuestro artículo en hebreo «Sephardic Folk-Literature and Eastern Mediterranean Oral Tradition», Jerusalem Studies in Jewish Folklore 5-6 (1984) págs. 7-22 y VII-X, o bien la versión en inglés en Musica Judaica 6 (1983-1984) págs. 38-54.

${ }^{3}$ Hasta ahora la lírica, pese a trabajos fundamentales de Manuel Alvar y Margit Frenk, ha sido bastante menos atendida que el romancero. Merecen por ello los mayores encomios la tesina (inédita) de Paloma Díaz Mas, Poesía luctuosa judeo-española [: Clasificación] (Univ. Complutense, Madrid 1977), así como el proyecto de catalogar las coplas que actualmente se lleva a cabo en la sección de Estudios Sefardíes del Instituto «Arias Montano». Sobre los distintos géneros folkliterarios y la relativa atención (o desatención) hacia ellos por parte de los estudiosos véase la excelente «Visión panorámica de la literatura sefardí» de I. M. Hassán, en Hispania Judaica: II Literatura, ed. J. M. Sola-SolÉ et al. (Barcelona 1982) págs. 25-44.

${ }^{4}$ Galante (1948) págs. 22-25.

${ }^{5}$ LURIA (1930) págs. 88-90. Contamos 33 textos, aunque de hecho hay 34, pues no creemos que «Ni primus ni parientis, ningunus di mi genti (Une pirsone sin amigus)» (pág. 90/73-74) sea adivinanza sino refrán: no encierra realmente ningún problema y responde a una idea proverbial frecuente: «Lo mesmo es Juana que su hermana» (Luisiana, inéd.) y otros que se podrían citar.

6 Azuz (1945). Hemos transcrito y estudiado los textos en nuestro artículo "Adivinanzas judeo-españolas de Turquía: los 'enigmas' del rabino Mẽnahẹem 'Azôz», en Philologica Hispaniensia in Honorem Manuel Alvar (Madrid 1983) vol. I págs. 81-92. 
díes de Turquía» (1963-1965) 7 . Aparte de estas cuatro colecciones orientales, lamentablemente exiguas, no hay nada. La literatura «enigmática» de los sefardíes de Marruecos se desconoce totalmente ${ }^{8}$.

En 1898-1899 el profesor William Milwitzky viajó extensamente por Oriente, visitando muchas comunidades sefardíes y reuniendo un rico acopio de materiales lingüísticos y de literatura tradicional: romances, canciones, cuentos tradicionales, proverbios ${ }^{9}$. Los materiales coleccionados por Milwitzky, resultado de entrevistas con judíos de Belgrado (Yugoslavia), Bucarest (Rumanía), Sofía y Plovdiv (Bulgaria), Salónica, Jíos y Rodas (Grecia) y Estambul (Turquía), pertenecen hoy a los fondos del Yivo Institute for Jewish Resarch de Nueva York. Hace años, gracias a la generosidad del entonces director Dr. Shlomo Noble, pudimos estudiar esta admirable colección y sacar de ella fotocopias, que según esperamos, servirán de base para una serie de monografías sobre su contenido.

Los «Papeles Milwitzky» son de carácter y calidad muy diversos: hay copias mecanografiadas, pulidas y ultimadas; otras transcripciones a mano, limpias y trabajadas; y otras más bien preliminares y tentativas, con correcciones y notas marginales. Pero una mayoría de los textos se encuentra en forma de

\footnotetext{
7 Elnecavé (1963) págs. 326-327.

8 Como puntos de contraste con esta lamentable situación se podrían señalar algunas de las ingentes colecciones representativas de otras áreas o tradiciones lingüísticas: la turco-otomana de BAşGÖZ y TIETZE (1973), la argentina de LEHMANN-NITSCHE (1911), o la de TAYLOR (1951) para la tradición inglesa (y sus extensiones ultramarinas), con notas comparativas de alcance mundial. En general, la adivinanza judía parece haberse desestimado: «Riddles are said to be unknown to certain peoples, notably the Jews, the Chinese, and the American Indians ... These assertions ... need critical examination» (TAYLOR [1951] pág. 3): es cierto. Para adivinanzas hebreas véase A. TAYLOR, A Bibliography of Riddles (Helsinki 1939) págs. 87-88; muchas referencias adicionales, así como a adivinanzas yemenitas y en yídico, se encuentran en H. Schwarzbaum, Studies in Jewish and World Folklore (Berlín 1968) págs. 423-424; pero con todo, observa Schwarzbaum: «As for Jewish Riddles little has been collected in this domain». Nótese también el breve artículo (falto de toda bibliografía) de R. RuBin, "Yiddish Riddles and Problems", New York Folklore Quarterly 12 (1956) págs. 257-260; y TAYLOR (1948) págs. 35-37, para enigmas medievales en hebreo de judíos españoles.

${ }_{9}^{9}$ Sobre los trabajos de Milwitzky, uno de los pioneros en las encuestas de campo sobre la lengua y literatura oral sefardíes, véase nuestro artículo (con $M$. SALA) «Un último eco del romancero sefardí de Bucarest», Anuario de Letras 10 (1972) págs. 233-236.
} 
apuntes de campo, aparentemente sin tocar desde aquel lejano y dramático momento en que fueron oídos y transcritos, a toda prisa y a veces incluso con inevitables lapsos y lagunas sin colmar, de boca de aquellos sefardíes "a la antigua», conocedores de una cultura entonces vigorosa y hoy a punto de extinguirse, en unas comunidades para nosotros ahora exóticas e irrevocables que han dejado de existir, o en todo caso, que sólo viven como reducidísimos restos o como recuerdos en la memoria de ancianos en algún rincón de la nueva diáspora del siglo XX. Los problemas editoriales que ofrecen los Papeles Milwitzky, sobre todo sus «cahiers» de campo, son por lo tanto complejos y a veces frustrantes, y las soluciones textuales tienen que quedar necesariamente tentativas en algún que otro caso.

Tal es la situación de cinco hojitas sueltas, obviamente apuntes de campo, copiados rápidamente e incompletos en algunos de sus componentes, que en nuestro primer repaso y catalogación de los Papeles Milwitzky habíamos pasado por alto, incluyéndolas, sin especificar su carácter distintivo, entre los abundantes refranes reunidos por Milwitzky. Un segundo repaso reciente de los materiales nos ha permitido enmendar semejante omisión.

Constituyen estas cinco hojitas (de unos 13 a $15 \times 10 \mathrm{cms}$.) una pequeña pero -dado el carácter limitadísimo de los demás testimonios- preciosa colección de nueve adivinanzas sefardíes (o -según está rotulada una de las hojillas- «enigmas»). Los textos fueron apuntados en Estambul, según se deduce de la atribución de otros materiales a uno de los informantes. Son un total de diez textos, pues el núm. 6 se reproduce en dos variantes ligeramente diferentes. Provienen, que sepamos, de dos informantes, un hombre y una mujer, identificados únicamente por su prenombre o apodo: "Behor", quien ofrece los núms. 1, 3, 7 y 8 , y «Vidutcha», conocedora de los núms. 4, 5 y $6 a$; los núms. 2, $6 b$ y 9 no llevan atribución. Creemos identificar en Behor un cierto gusto (¿masculino?) por los acertijos de doble sentido, picarescos e incluso escabrosos (Griffrätsel) ${ }^{10}$, como lo son los núms. 1, 3 y 7, mientras Vidutcha quizás refleje un repertorio de tono más correcto.

${ }^{10}$ Sobre este tipo de adivinanzas véanse K. W. Clarke, «Griffrätsel at Home and Abroad», Western Folklore 26 (1967) págs. 119-121; para la tradición hispánica, Plath (1969) págs. 41-49, y el libro francamente pornográfico de PAREDES Candia (1976). 
En lo que sigue conservamos intacta la ortografía original de Milwitzky, reemplazando solo su $\hat{c}$ por $h$ y supliendo algunos acentos, la puntuación y la división de "versos». El signo de interrogación que figura al final de algunas adivinanzas lo interpretamos como abreviatura de la pregunta "¿Quálo es?» (núm. $6 a$ ), que suplimos en los casos indicados.

Dado que la adivinanza es una forma estructuralmente sencilla ${ }^{11}$, ofrece problemas mucho mayores para la identificación de sus posibles congéneres peninsulares -sobre todo a través de cinco siglos de separación geográfico-cultural- que una forma más compleja, como lo es, por ejemplo, el romance, que suele incorporar un intrincado argumento narrativo compuesto de múltiples segmentos y motivos ordenados de un modo muy peculiar y distintivo. El problema de la identificación de paralelos genéticos de las adivinanzas nos recuerda la exploración de la lírica primitiva ${ }^{12}$, tan exuberantemente provista de escollos peligrosos, en donde, por la misma brevedad y sencillez de los textos, tiene que entrar constantemente en juego la cuestión planteada por Dámaso Alonso en su magistral estudio «¿Tradición o poligénesis?» ${ }^{13}$. En lo que sigue, nuestras identificaciones se ofrecen como tentativas y han de ponderarse con toda la cautela invocada en estas observaciones preliminares. He aquí los textos:

${ }^{11}$ Es también, claro está, una forma primordial, fundamental, en el sentido en que lo entiende André Jolles en su interesante libro Einfache Formen: Legende, Sage, Mythe, Rätsel, Spruch, Kasus, Memorabile, Märchen, Witz (Halle [Saale] 1930; $5^{\mathrm{a}}$ ed. Tübingen 1974; eds. española y francesa: Las formas simples [Santiago de Chile 1972] y Formes simples [París 1972]). Por estimulantes que sean las ideas de Jolles, es curioso observar en qué acaba la teoría frente a la práctica; véase la importante crítica, justificadamente severa en algunos casos (págs. 203 y 205-206), de TAYLOR, conocedor como nadie ha sido ni lo será de la literatura enigmática mundial: «The Riddle as a Primary Form», en Folklore in Action: Essays ... in Honor of McEdward Leach, ed. Horace P. BEck (Filadelfia 1962) págs. 200-207.

12 Véase el fino libro de M. Frenk, Las jarchas mozárabes y los comienzos de la lírica románica (México 1975). Para una tentativa muestra de identificación genética de una jarcha con textos más recientes, véase nuestro artículo « $L a$ sanjuanada: ¿Huellas de una harğa en la tradición actual?», Nueva Revista de Filología Hispánica 18 (1965-1966) págs. 436-443 (refundido ahora en En torno, cap. I.1).

13 «¿Tradición o poligénesis?», Boletín de la Biblioteca Menéndez Pelayo 39 (1963) págs. 5-27, o bien «Tradition or Polygenesis?», Modern Humanities Research Association 32 (nov. 1960) págs. 17-34. 
1. El día 'ncolgando,

la notche en el buraco.

(L'andravica de la puerta.)

La palabra andravica ofrece algunas dificultades: en el manuscrito la segunda letra podría leerse también $u$; y la que hemos leído tentativamente como $v$ parece haber sido originalmente una $n$, alterada después a algo que bien puede leerse $v$; pero la lectura queda incierta. Sea ésta la que fuere, la palabra judeoespañola corresponde obviamente al castellano aldabilla: nótese cómo en portugués existe la forma aldraba o aldrava (frente al castellano aldaba), reflejo quizá de la influencia semántico-morfológica de la raíz árabe $D \cdot R \cdot B$ 'pegar', que explicaría la - $r$ - de nuestra voz judeoespañola. La - $n$ - ha de representar una nasalización de -l- (alveolares las dos) por la razón que sea, sin duda bajo la influencia de alguna otra palabra con comienzo en an-.

Hay adivinanzas griegas y turcas análogas, referentes al pestillo de la puerta, aunque reflejan menos obviamente la ambigüedad de nuestro Griffrätsel sefardí; véanse los siguientes ejemplos, de Jíos:
Tèn hēméran krémetai
De día cuelga
kaì tè nýchta stéketai.
$y$ de noche para
([Mándalon] $)^{14}$
(El cerrojo);

de Macedonia:
Hólē méra kremasménòs Todo el día colgante
kaì tò brády sēkōménos. y al anochecer levantando.
(Mántalos) ${ }^{15} \quad$ (El cerrojo);

o de Turquía:

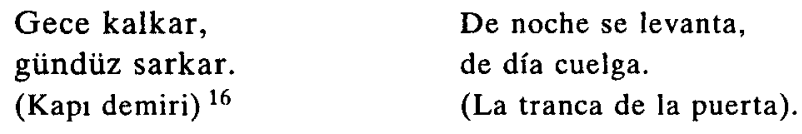

\footnotetext{
${ }^{14}$ Argenti-Rose (1949) pág. 967 (núm. 66); no consta en esta colección el original griego de las soluciones.

15 Aвbott (1903) 44. Para otro ejemplo griego véase Politis (1871) 102.

16 Hamamizade (1930) 321. Para más textos turcos véase la monumental colección de BAşGöz-TIETZE (1973) 233.3. Compárese también la adivinanza albanesa
} 
Pero a pesar de la semejanza de estas adivinanzas orientales con nuestro texto sefardí, aún nos parece posible, si no muy probable, que éste haya tenido su origen en la tradición hispana. Aunque no goza, al parecer, de especial popularidad, en varias subtradiciones (España, Santo Domingo, Puerto Rico, Perú y Chile) se conoce un enigma parecido aunque menos sugerente. Lo que tiende a persuadirnos de su afinidad genética con nuestra adivinanza sefardí es el hecho de que todas estas adivinanzas hispano-occidentales no sólo reflejan esencialmente la misma idea, sino que también tienen asonancia en á-o. Citamos variantes de España:

De día cargando,

de noche apretando.

(El palo para atrancar la puerta) ${ }^{17}$;

de Santo Domingo:

De día colgando

y de noche apretando.

(La aldaba) ${ }^{18}$;

y de Puerto Rico:

De día colgando

y por la noche descansando.

(La aldaba) ${ }^{19}$.

2. Quatro pyes y quatro xentos,

byen mi asenya son quinyentos, avlar y bovear quinze.

(L'âne [escrito al final de la explicación]. L'âne a quatre pieds et fait quatre cents pas, peut-être cinq cents [las tres últimas palabras en adición supralineal], mais ne les compte pas [aquí parece que terminaba el texto; pero se añaden

que traduce Pedersen (1898): «Tags in einem Loch, nachts in zwei (Der Riegel)» (pág. 109 núm. 18).

17 Rodriguez Marín (1951) 721.

18 Garrido de Boggs (1955) 344.

19 Ramírez de Arellano (1926) pág. 257 (núm. 369d). Otros ejemplos hispánicos: Demófilo (1880) 990; ANdRADE (1930) 20a-c; MoRote Best (1950) 68-69; Flores (1911) 742; Pino Sepúlveda (1971) pág. 33. 
dos palabras, luego tachadas, que podrían leerse pour lui, y a continuación:] à peu près son[t] cinquante [sic; la última palabra aparece también tachada y sobre ella escrito cinq cen[ts], que resulta a su vez tachado por un trazo largo que marca la separación entre adivinanzas].)

Hasta la fecha no hemos encontrado en las diversas tradiciones nada que se parezca a este texto sefardí. La solución, según la presenta Milwitzky, queda confusa y trunca. Obviamente se trata de una adivinanza narrativa parecida a nuestro núm. 4 , pero el sentido exacto ha de quedar pendiente hasta que se descubra un texto y sobre todo una solución mejor conservados.

3. Mi peludo cave 'n 'vestro buraco!

Cave i recave, k'alimpyadico stá.

(El cavayo.)

Huelga decir que se trata de un Griffrätsel: al montar, el caballo cabe entre las piernas del jinete. Aunque no se puede afirmar nada con completa seguridad, la adivinanza parece de origen hispánico. En varias subtradiciones circulan enigmas de intención similar; compárense los siguientes de Puerto Rico y Guatemala:

Largo y peludo

y es para tu culo.

(Caballo) ${ }^{20}$;

de Bolivia y Chile:

¿Qué será y qué será?

Largo y peludo,

cabal para tu culo.

(El pellón de montar) ${ }^{21}$;

\footnotetext{
${ }^{20}$ Puerto Rico: Mason (1960) 110; Guatemala: Recinos (1918) 7.

${ }^{21}$ Bolivia: Paredes Candia (1953) pág. 127; Paredes Candia (1976) págs. 21-22; Chile: Plath (1969) pág. 48.
} 
o de Cuba y Colombia:

Gordo lo tengo, más lo quisiera, que entre las piernas no me cupiera. (El caballo $)^{22}$.

4. -Tú te huites i venites,

kwatro pyes, ¿ké izites?

-Kwatro, kwatrosyentos;

syento, byen m'asento;

dale fuye y.kinze;

kita y mete, ventesinco.

[¿Quálo es]?

(El kavayo, ahuera su cwara, que se 'mbenea el benadam enriva.)

El giro "ahuera su $c^{w}$ ara» no forma parte de la solución; responde más bien a una fórmula de cortesía expresada por la informante (Vidutcha), que significa algo así como las expresiones populares españolas «usted disculpe» o «con perdón de los presentes». Compárese la traducción del giro al alemán en un cuento tradicional de Constantinopla publicado por Wagner; en un diálogo entre gatos, dice uno: «Iá tenéš mũnčos pekados -(¡ahuera las karas!)- tãntos ratones ke tenéš matado» $=$ «Freilich habt ihr viele Sünden - mit Verlaub zu sagen-die vielen Mäuse, die ihr getötet habt» ${ }^{23}$. Figura la expresión asimismo en un relato de José y la mujer de Putifar dicho por una de nuestras informantes de Rodas: «Si, dizi, kara de zuná, afuera las karas i la kaza, dišu, tú buškatis, dize, a él i tuvites kara, kuraži» ${ }^{24}$ (la palabra ofensiva zuná es del hb. zoná 'pros-

22 Cuba: Giménez Cabrera (1926-1927) 63; Massip (1924-1925) 36; Colombia: Velásouez (1960) 94; también se dice igual en España. Compárese la forma italiana: «Quale e quella cosa: Grande e grosso lo vorria, / tra le gambe mel metteria, / dritto dritto vorrei che andasse / e che mai non scappuzzasse (Cavallo)» (TSCHIEDEL [1896] 15).

${ }^{23}$ M. L. WAGNER, Beiträge zur Kenntnis des Judenspanischen von Konstantinopel (Viena 1914) cols. 63 y 64 (simplificada la transcripción).

${ }^{24}$ Dicho por la Sra. Cadén Capeluto, de 83 años, el 22 de junio de 1958 en Albany (California). 
tituta') ${ }^{25}$. El verbo embenear es del turco binmek 'montar a caballo, cabalgar'; benadam corresponde al hebreo ben-'adam 'persona'.

Esta adivinanza narrativa, tal como se presenta en los apuntes de campo de Milwitzky, queda algo menos que transparente, debido primordialmente a lo incompleto de la solución. Elnecavé (1963) ha publicado un texto análogo y mucho más satisfactorio (págs. 326-327):

-Tú ke fwuitez i venites,

por los kwatro: ¿ké izites?

-Kwatro - kwatrosyentos,

syento - byen m'asento,

dale-fuye - kinse,

kita-i-mete - vente i sinko.

Un señor pide a su criado que venda su caballo con los arreos y le pregunta por cuánto lo vendió. El criado le responde que vendió el caballo (de cuatro patas) por cuatrocientas monedas, por cien la montura, el látigo por quince y el estribo por veinticinco.

El enigma debía ser muy popular en Oriente, pues Galante (1948) también recoge una variante de sentido análogo (págs. 24-25):

Onde fuites y venites,

el de quatro qué hicites?

El de quatro (cavallo) quatro cientos,

el que me asento (silla, albarda), cien,

el quita y mete (estribo) diez y seş,

el dale y hui (azotes) quince pesetas vendí.

${ }^{25}$ Nótese que en árabe occidental, al nombrar algún animal o algo desagradable o sujeto a un tabú, se suele añadir la expresión haša-ki 'lejos de ti, a salvo vuestro respeto' (véase J. T. Monroe, Hispano-Arabic Poetry [Berkeley - Los Angeles 1974] pág. 185 nota al v. 47). En último término conviene comparar nuestro giro con otras expresiones propiciatorias corrientes en los dialectos judeoespañoles, como por ejemplo la marroquí ferazmal o feražmal (= fuera de mal), la oriental eskapadižo de mal, o bien escapado de mal o barmin(n)án ('Dios nos libre', aram. bar minán) corrientes en ambas tradiciones; véanse J. BENOLIEL, «Dialecto judeohispano-marroquí o hakitía", Boletín de la Real Aacademia Española 13 (1926) págs. 209-233, 342-363 y 507-538; 14 (1927) págs. 137-168, 196-234, 357-373 y 566580; 15 (1928) págs. 47-61 y 188-233; 23 (1952) págs. 255-289: 13 (1926) pág. 219, 14 (1927) pág. $576 a$ y $15(1928)$ págs. $60 b$ y $189 b$; y J. Nehama, Dictionnaire $d u$ judéo-espagnol (Madrid 1977) págs. $80 a$ y $187 b$. 
Hay adivinanzas parecidas en otras áreas hispánicas, aunque son bastante raras, al menos en las fuentes publicadas. Del ámbito lingüístico español sólo conocemos ejemplos de Puerto Rico:

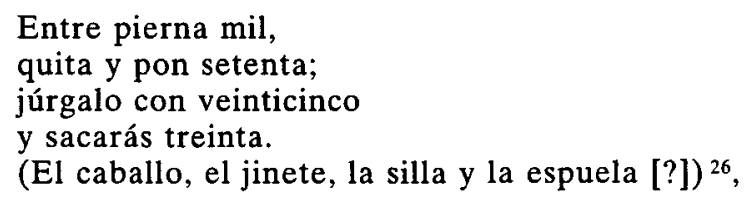

y del Ecuador:

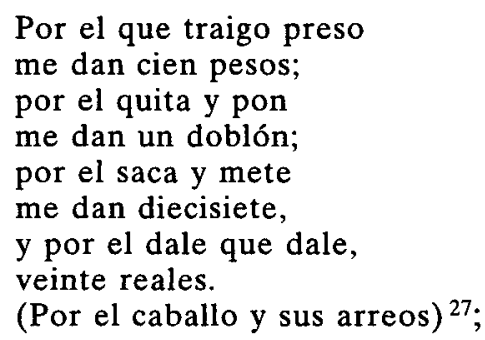

amén de una adivinanza portuguesa del Alemtejo:

P'lo andante dã cento i vinte, pelo tira sacca doze; tirem-se os nuvrados, contaremos as estrellas.

Era un criado que vendê um cavallo đê-o por menos 12 mel reis que o dono le disse. Dê aquelle recado em frente das visitas que estavam com o amo; as visitas eram os nuvrados, as estrellas eram as moedas ${ }^{28}$.

Ninguno de estos textos hispánicos parece suficientemente afín a nuestro enigma sefardí como para que podamos estar completamente seguros de que la derivación de ésta sea peninsular: podría basarse en alguna otra tradición, oriental quizá. No hemos encontrado hasta ahora nada análogo en griego ni en turco; nótese, sin embargo, la siguiente adivinanza en árabe argelino:

${ }^{26}$ MASON (1960) 109 (también 107-108).

27 Cornejo (1948) 296.

${ }^{28}$ Pires (1884) 117. La interpretación «dê-o por menos $12 \mathrm{mel}$ reis que o dono le disse" no parece acertada; tira-sacca debe referirse, al ejemplo de las demás variantes, a algún arreo del caballo: la silla, el estribo o la brida. 

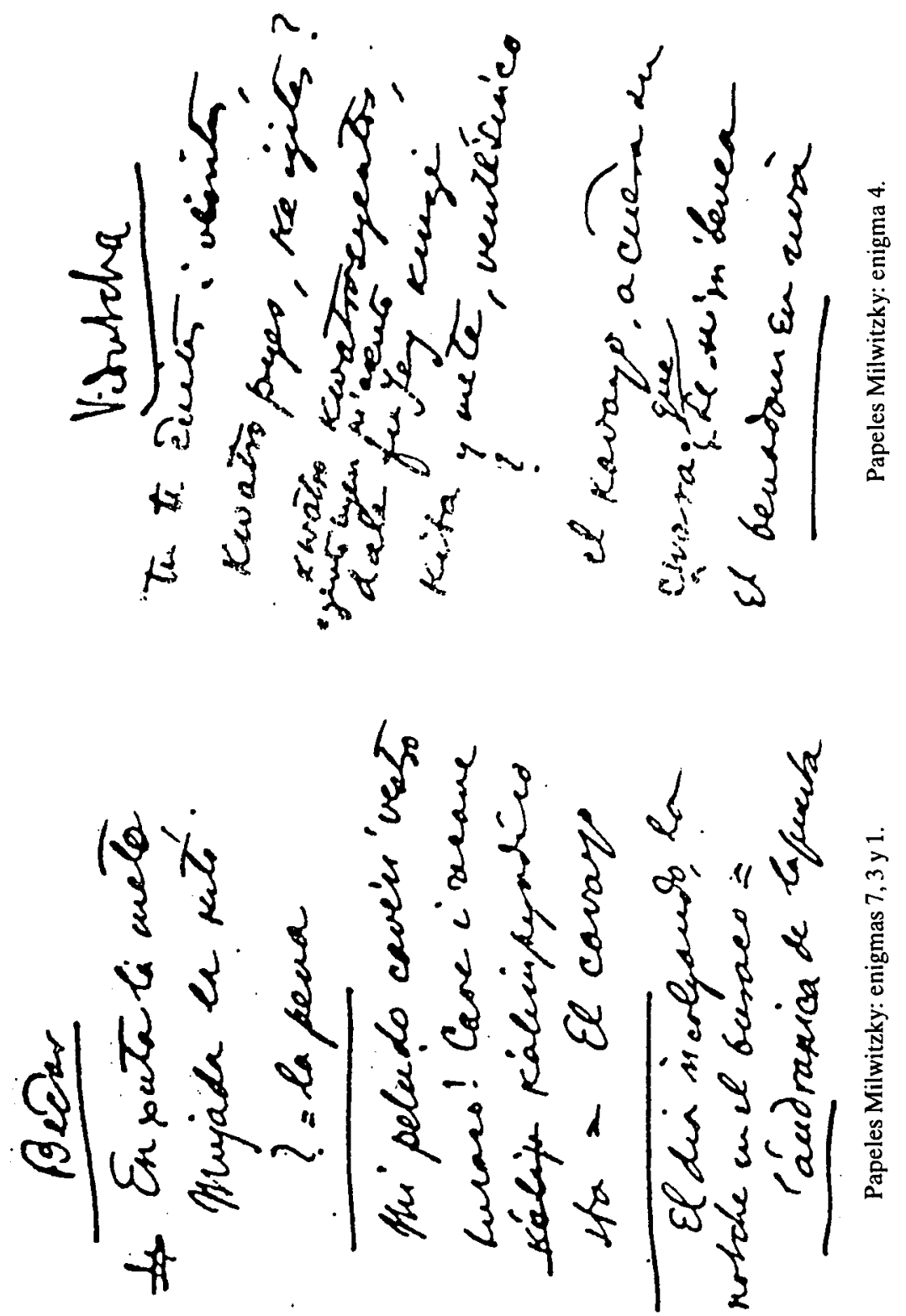
Arba' b-ârba'în,

Quatre pour quarante,

oû erfed oû h'at't' b-'achra, enlève et mets pour dix,

oû dekhkhel oû kherredj b-khamsa. fais entrer et fais sortir pour cinq. ('Aoûd oû serdj oû ldjâm) (Le cheval, la selle et la bride).

Un homme avait envoyé son serviteur vendre son cheval. A son retour le serviteur vint rendre compte a son maître, et pour ne pas être compris des assistants, il s'exprima dans les termes ci-dessus. Cela veut dire: J'ai vendu les quatre pattes ou le cheval pour quarante douros; la selle qui s'enlève et se met, pour dix, et la bride que l'on fait entrer dans la bouche et sortir, pour cinq douros ${ }^{29}$.

5. Riyendo abaxa,

yorando suve.

[¿Quálo es]?

(El kuvo del pozo; l'abaxamos xuto, vazyóse.)

En la colección del rabino Azuz (1945) consta una variante de sentido idéntico: «Abaša riendo, / asuve yorando ( $\mathrm{El} \mathrm{cu-}$ bo)» (núm. 8); y también Galante (1948) recoge el enigma: «Abassa riendo y subi llorando. ¿Quién es? (Caldero)» (pág. 23; modificamos la puntuación). No cabe duda, según creemos, del origen hispánico de esta adivinanza; constan textos muy similares de Puerto Rico:

Cuando baja, va cantando, cuando sube, va llorando. (El balde) ${ }^{30}$;

y de Argentina:

Baja riéndose

y sube llorando.

(El balde) ${ }^{31}$.

${ }^{29}$ Giacobetti (1916) 468. Interesante es notar que la maqama 29 de Al-Hamadhani trae una larguísima descripción de un caballo en forma de adivinanza y a base de números; véase The Maqämāt of Bad $\bar{I}^{\prime}$ al-Zamān al-Hamadhān $\bar{\imath}$, trad. W. J. Prendergast (reed. Londres - Dublín 1973) págs. 120-122.

30 Ramírez de Arellano (1926) pág. 261 (núm. 393a).

31 Lehmann-Nitsche (1911) $133 g$ (también $h$-j); otros ejemplos argentinos: CARRIzo (1942) 4676; JiJena SánCHEZ (1948) 50; MoYa (1955) pág. 111; VillafuerTe (1975) 464. 

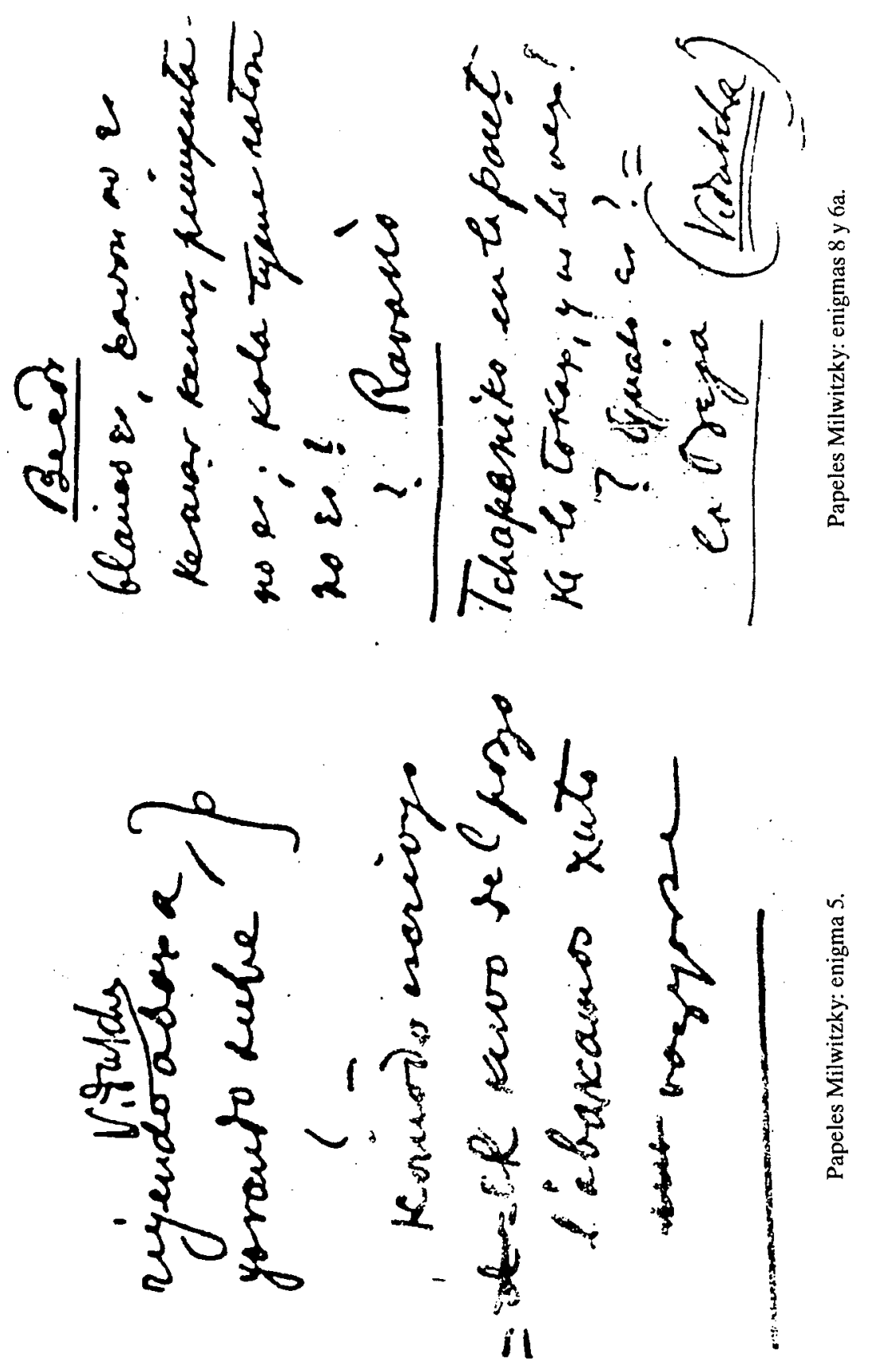
Por otra parte, según ya hemos señalado respecto al texto de Azuz, conviene tener en cuenta la siguiente analogía turca que incorpora la misma idea y puede quizás haber «reforzado» la adivinanza sefardí:

Aşaği inerken kıkır kıkır güler yukarı çıkarken sspır şspır ağlar. (Kova) ${ }^{32}$

Al bajar, se ríe kikir kikir; al subir, vierte lágrimas ssipir sipir. (El cubo).

La adivinanza tiene amplia distribución internacional, y como observa Taylor, varios de los ejemplos bien pueden ser de origen poligenético. Consta también en lengua inglesa, como lo demuestra la siguiente versión antillana (de la isla de S. Martín), entre otros textos recogidos por Taylor: «Something gone down laughin' an' comin' up cryin' - Bucket» ${ }^{33}$.

6a. Tchapeniko en la paret

ke lo tokáx y no lo vex.

¿Quálo es?

(Là oreja.)

6b. Tchapiniko en la parè;

lo tuc"áx y no lu vex.

(Oreille.)

En segunda línea de la versión $b$, la primera vocal de la segunda palabra podría leerse en el manuscrito tanto $o$ corregida en $u$ como al contrario. En la misma línea, a la primera letra de la primera palabra parece preceder un signo, que no se lee.

También consta en la colección de Azuz (1945) en forma casi idéntica: «Čapiniko ('eskarpiniko) 'a la pared; / lo tokáš 'i

\footnotetext{
32 BaşGöZ-TiETZe (1973) 102.8; ÖGel (1950) 79.

${ }^{33}$ TAYLOR (1951) págs. 278-280 (núms. 768-769), donde también se citan ejemplos en otras muchas tradiciones. Compárese también este de Italia: «Semo quele che va via cantando / e che le torna a casa lagrimando (Conche d'acqua)» (Tschiedel [1896] 24), así como los siguientes ejemplos francés, provenzal y catalán: "Qui est-ce qui rit en descendant et pleure en remontant? (Le seau d'eau)» (Rolland [1877] 223); «Que qu'ei? Que ris en davalant / et pura (pleure) en mountant (Lou selhou d'un pous)» (Rolland ibid.); «Qu'es aixó: Quant baixa riu y quant puja plora? (La galleda)» (MiLÁ Y Fontanals [1876] 11; AMADEs [1951] pág. 1272 [núms. 553-554]). LURIA (1930) recoge otro enigma sobre el cubo, diferente pero no del todo ajeno: «Provi abaše, ricu asuvi (La cuvá d'ague)» (pág. 90/65-66), cuyo origen desconocemos (cuvá es del tc. kova).
} 
no lo wweš [La oreja]» (núm. 5=1); y en la de Galante (1948): «Sapatico colgado en la pared, lo toco, ma no lo veigo (Oreja)» (pág. 23). Pero no hemos visto nada semejante, ni por lo más remoto, en ninguna otra subtradición hispánica. Ha de ser de origen turco; consta su primera parte en el siguiente enigma turco, de gran difusión:

$\begin{array}{ll}\text { Yarım kaşık } & \text { Media cuchara } \\ \text { duvara yapışık } & \text { pegada a la pared. } \\ \text { (Kulak) }{ }^{34} & \text { (La oreja). }\end{array}$

En cuanto a la segunda parte, la idea de que la oreja no se ve se relaciona, probablemente, con un tópico de gran difusión en el repertorio enigmático internacional. Se trata generalmente de los ojos ${ }^{35}$, como en el texto judeoespañol de Monastir que recoge Luria (1930): «Doz irmanus caminandu istán y no si veyin (Luz ojus)» (pág. 90/55-56); pero en algún ejemplo se aplica la misma idea también a las orejas, como en la adivinanza inglesa de Bermuda: «Jack on one side. Tom on the other; and yet Jack cannot see Tom (Ears)» 36 ; o en el siguiente texto puertorriqueño: «Dos hermanitas, ni se ven, ni se visitan (Las orejas)» ${ }^{37}$.

7. Enxuta la meto,

mujada la kito.

[¿Quálo es]?

(La pena.)

Trátase de la pluma de escribir; la forma pena puede provenir del italiano o bien del portugués. Es imposible saber el origen de la adivinanza, que ejemplifica una imagen de doble sentido aplicada a una infinitud de objetos diferentes en la enigmática internacional ${ }^{38}$. Ténganse en cuenta los siguientes ejemplos hispánicos, de Puerto Rico:

\footnotetext{
34 Başgöz-Tietze (1973) 254.12, 11; 914.1; también Kowalski (1932a) 83; Kowalski (1932b) 5; Ögel (1950) 93, donde en vez de una cuchara se trata de un colador o un cucharón.

${ }^{35}$ TAYlor (1951) págs. 386-390 y 788-789.

36 TAYlor (1951) pág. 390 (núm. 1004).

37 Mason (1960) 408; también Lehmann-Nitsche (1911) 399.

38 Véase TAYLoR (1951) págs. 600-602, 846 (núms. 1448-1452); más ejemplos griegos: Abbott (1903) pág. 368 (núm. 9); Argentr-Rose (1949) pág. 945 (núm. 28); Dieterich (1908) pág. 416 (núm. 16).
} 
Lo meto seco

y lo saco mojado

y la punta colorada.

(Cigarrillo) ${ }^{39}$;

de Cuba y Argentina:

Mételo seco

y sácalo mojado.

(Cubo) ${ }^{40}$;

de Portugal:

$$
\begin{aligned}
& \text { Tranglomanglo, } \\
& \text { mete-se enxuto } \\
& \text { e sai pingando! } \\
& \text { O que é? } \\
& \text { (O copo })^{41} \text {; }
\end{aligned}
$$

de Brasil:
João Curto, desconfiado;
entra enxuto e sai molhado.
(Côco de beber água) ${ }^{42}$;

o de Cabo Verde:

Pô sec', tira molhad'.

(Calman) ${ }^{43}$.

39 Mason (1960) 167, cfr. 167b. El texto escapó a los esfuerzos expurgatorios del editor: «Una pequeña parte de las adivinanzas ... no fue impresa por considerarlas ya ofensivas al buen gusto ...» (pág. 15); para más sobre esto véase el artículo de S. G. ARmisteAd, «Adivinanzas españolas de Luisiana», en Homenaje a Alvaro Galmés de Fuentes (Madrid 1995) vol. II págs. 251-262: pág. 255 nota 14.

40 Cuba: MAssip (1924-1925) 70; Argentina: Moya (1955) pág. 111. Hay ejemplos griegos y turcos similares aplicados al cubo: ArgenTr-Rose (1949) pág. 946 (núm. 34); BaşGöz-TIETZE (1973) 102.1; Kowalski (1932b) 54. ¿Habrá un eco de esta adivinanza en lo que añade Vidutcha a la solución del núm. 5: «l'abaxamos xuto ...»?

41 VALLE (1966) 44.

42 Melo (1950) págs. 286-287.

${ }^{43}$ Parsons (1923) pág. 252 (núm. 220); en el dialecto criollo, calman representa una calabacita para recoger agua (huelga, por obvia, la observación de Parsons: «This has a double meaning»). Para otras adivinanzas hispánicas de sentido similar véanse, por ejemplo, ANDrade (1930) 186a-b; CoRnejo (1948) 237; Moya (1955) pág. 141; Plath (1969) pág. 48; Velásquez (1960) 121. 
En algún caso raro la idea se aplica a la pluma en otras subtradiciones hispánicas, como en el siguiente ejemplo portugués:

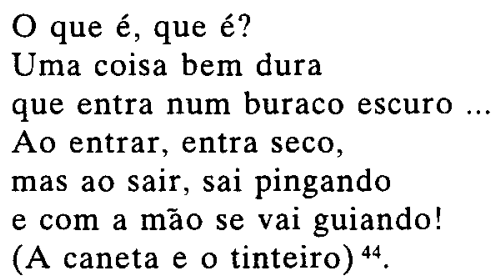

No es frecuente tampoco en otras tradiciones la relación con la pluma ${ }^{45}$; compárese una forma italiana: «Qual è quella cosa che ha il capo forato, / mettesi asciutto e cavasi bagnato? (Penna)» ${ }^{46}$. En suma: resulta difícil señalar con certeza un origen específico.

8. Blanco es, xavón no es;

kemar kema, pimyenta no es;

kola tyene, ratón no es.

[¿Quálo es]?

(Ravanò.)

La adivinanza encierra un par de características -blancura, picante- presentes también en varios enigmas hispanos; de España y Argentina:

Blanco como er papé; colorao com er clabé; pica y pimienta no es. (El rábano) ${ }^{47}$;

o de Portugal:

E'verde, não é limão, encarnado, não é sangue, é branco, não é papel.

(O rábão: rábano $)^{48}$.

\footnotetext{
44 Valle (1966) 42.

45 TAYLOR (1951) pág. 601 (sección 10).

46 TSCHIEdel (1896) 63.

${ }^{47}$ España: Rodríguez Marín (1951) 516; Caballero (1961) 49; Argentina: CARRIZO (1942) 5022.

${ }^{48}$ Pires (1887-1889) 7; Pires (1884) 34; PIRes (1888) 21.
} 
No cabe duda sin embargo, según creemos, de que la adivinanza judeoespañola no es de origen peninsular. Su semejanza con varios enigmas balcánico-orientales es mucho mayor: blanco como jabón/queso, rabudo como ratón; compárense los siguientes ejemplos en griego:

'Àspro eìnai sàn tyrì kaî̀ tyrì dèn eìnai;

fýlla 'échei sàn dentrì

kaî̀ dentrì dèn eìnai;

'échei mpontikoũ 'orà

kaì mpontikòs dèn eìnai

(Tò 'rapáni) ${ }^{49}$

en serbocroata:

Belo je, sir nije;

rep ima, miš nije.

(Rotkva) ${ }^{50}$

o en turco:

Başı yeşil, emir değil; uistü kara kömür değil; içi beyaz, peynir değil; kuyruğu var, fare değil. (Turp) $^{51}$
Blanco es como queso

y queso no es;

hojas tiene como árbol

y árbol no es;

tiene cola de ratón

y ratón no es.

(El rábano);

Blanco es, queso no es; cola tiene, ratón no es. (Rábano);

Su cabeza es verde, emir no es; su exterior es negro, carbón no es; su interior es blanco, queso no es; cola tiene, ratón no es.

(Rábano).

Como en el caso de muchos «balcanismos» lingüísticos ${ }^{52}$, resulta difícil precisar el origen inmediato del texto. Siendo de Estambul, podría haber tenido como fuente una versión turca; huelga decir, sin embargo, que la presencia griega en la metrópoli siempre ha sido de gran importancia. Por la semejanza de su estructura tripartita $-\mathrm{y}$ en contraste con la presencia de otros elementos ajenos en el texto turco: verde/emir, negro/

49 Stathes (1910) 26; más variantes: Argentr-Rose (1949) pág. 975 (núm. 4); Bafeiados (1974) pág. 126; IoANnides (1870) pág. 271; PAPACHRISTOdoulos (1910) 2; Politis (1871) 248; Zervopoulou (1966) 15; también Dieterich (1904) pág. 93.

${ }^{50}$ Novaković (1877) págs. 194-195.

${ }^{51}$ BaşGöZ-TIETZE (1973) 611.7; en pág. 825 nota 146, los autores explican que un emir, como descendiente del Profeta, llevaría un turbante de color verde; véase también la pág. 817 nota 13.

52 Véase E. Stankiewicz, "Balkan and Slavic Elements in the Judeo-Spanish of Yugoslavia», en For Max Weinreich ... (La Haya 1964) págs. 229-236, especialmente la pág. 232. 


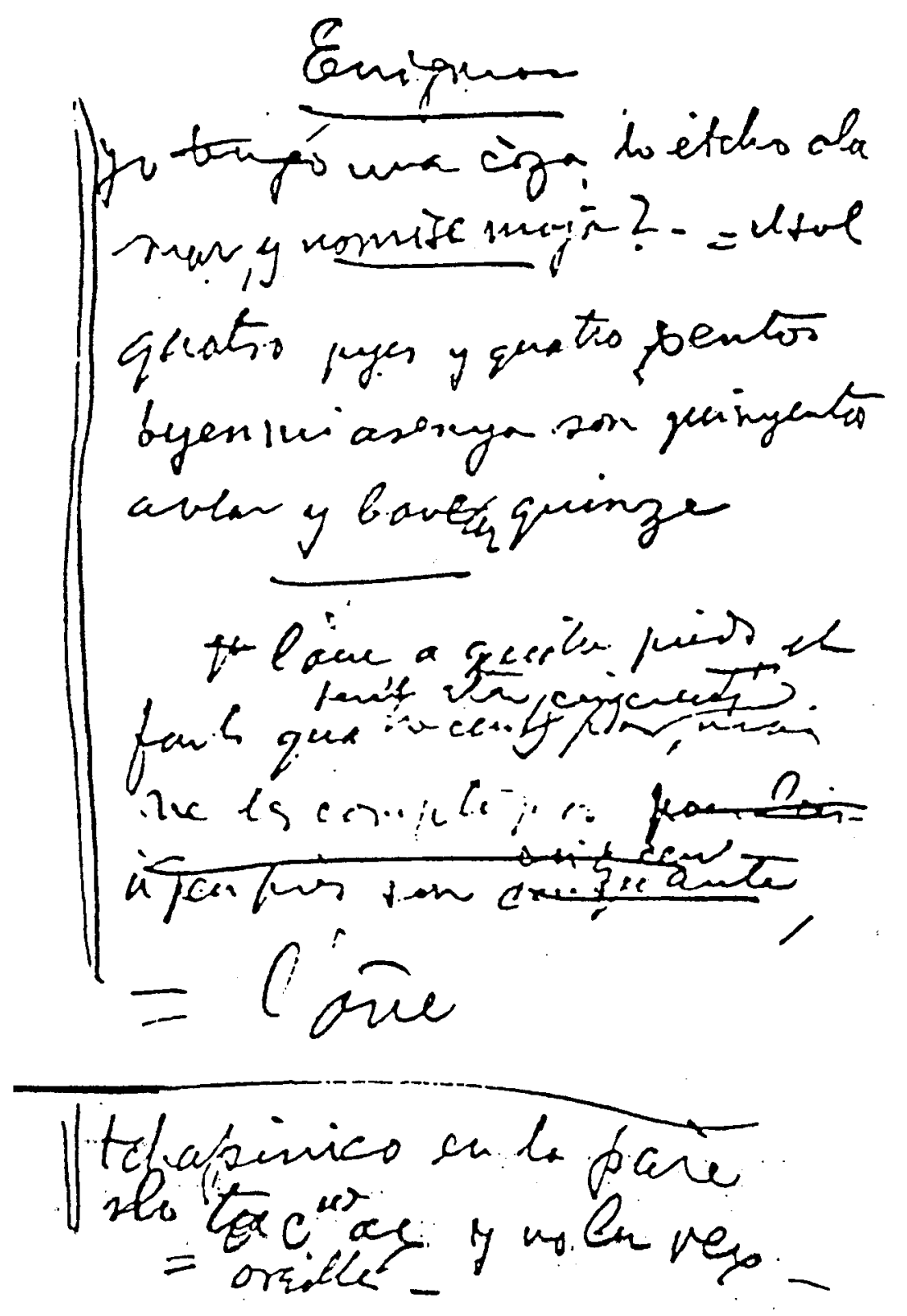

Papeles Milwitzky: enigmas 9, 2 y 6 b. 
carbón-, tendemos a preferir la versión griega como la fuente más próxima de nuestra adivinanza sefardí.

9. Yo tengo una coza;

lo etcho a la mar

y no mi se moja.

[¿Quálo es]?

(El sol.)

La recogen también Luria (1930): «Al ague 'stá, no si moje (Il sol)» (pág. 88/10-11); y Galante (1948): «A la mar lo echo y no se moja (El sol)» (pág. 22). La idea de que el sol, o bien los rayos del sol, pasan por el agua y no se mojan se conoce en muchas tradiciones ${ }^{53}$. Como parte de una adivinanza de contestación múltiple (el sol, el papel, el muerto, el oro) existe en turco:

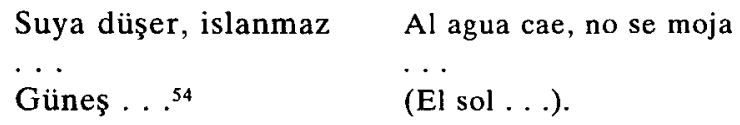

Pero existe también en la tradición hispánica, aunque resultan ser bastante escasos los ejemplos; véanse los siguientes de España:

¿Qué cosa es cosa

que entra en el agua y no se moja?

(Los rayos del sol) ${ }^{55}$

o de Argentina y de Chile:

Hay una cosa

que entra al agua y no se moja.

¿Qué será?

(El sol) ${ }^{56}$.

53 Véase TAYLOR (1951) págs. 59-62, así como los artículos TAylor (1936) y TAYLOR (1938) pág. 7.

${ }^{54}$ BaşGoz-Tietze (1973) 1040.

55 Rodríguez Marín (1951) 252; Demófilo (1880) 847; Caballero (1961) 15.

56 Argentina: Lehmann-Nitsche (1911) $107 \mathrm{~h}$, cfr. $107 \mathrm{~g}$, 516; Jijena Sánchez (1948) 386; Chile: Flores (1911) 705-706. Nótese también el texto catalán que recoge BRIZ (1882) 134, y el paralelo francés allí citado (de Rolland [1877] págs. 2-3, quien a su vez aduce analogias de otras lenguas).

Algo más frecuente en la tradición hispánica es que la misma idea se aplique a la sombra, como también en otras muchas tradiciones (TAYLOR [1951] págs. 59-60), pero no faltan otras soluciones hispánicas bastante diversas: la luna (MASsIP [1924-1925] 176; 
La adivinanza es, incluso, una de las relativamente pocas de la que tenemos textos antiguos ${ }^{57}$. En forma análoga a las versiones modernas, figura en los Juegos de noches buenas a lo divino (Barcelona: Sebastián Cormellas, 1605) del segoviano Alonso de Ledesma:

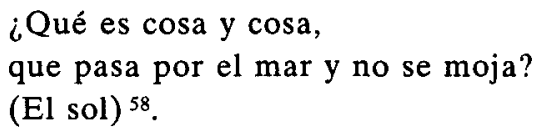

CoRnejo [1948] 310); el aire (Morote Best [1950] 52); la nube (ANDRAde [1930] 222); el grito (Melo [1950] págs. 207-209). Para ejemplos hispánicos de la sombra que no se moja véanse los textos de España: Demófilo (1880) 935; Rodríguez Marín (1951) 899; de Nuevo México: Campa (1937) 89; Espinosa (1915) 120; de Cuba: Massip (1924-1925) 176; de Santo Domingo: Andrade (1930) 278a-b; GarRIDo (1955) 590; de Puerto Rico: MASON (1960) 660; de El Salvador: BaratTa (1952) pág. 591; de Panamá: Robe (1963) 108; de Colombia: Beutler (1963) 7; Reichel-Dolmatoff (1956) pág. 112; VelásoueZ (1960) 16; del Ecuador: Cornejo (1948) 87a-b, 310; Mena (1970) 48; del Perú: ColáN Secas (1948) 101; de Bolivia: Paredes Candia (1953) pág. 127; de la Argentina: Jisena Sánchez (1948) 435; Lehmann-Nitsche (1911) 107a-f; Moya (1955) pág. 61; de Chile: Dufourco (1941-1943) 41; Rivadeneira (1939) pág. 129 (núm. 132); Soustelle (1938) 27; del Brasil: Almeida Oliveira (1940) 14; Melo (1948) 7; Melo (1950) trae algunos ejemplos adicionales (págs. 208-210).

Se trata, en efecto, de la misma adivinanza. Quizá la característica más destacada de las adivinanzas tradicionales sea la radical variabilidad de las soluciones: una misma adivinanza puede tener múltiples soluciones diferentes. La observación de KowALSKI (1932b) respecto a las adivinanzas turcas podría ser axiomática para cualquier tradición: «... die Lösung das am meisten schwankende und unbestimmte Element des Rätsels bildet" (pág. 131); el concepto informa el genial sistema desarrollado por TAYLOR (1951) págs. 3-4. Sobre la inestabilidad de las soluciones en la tradición hispánica véanse Boggs-GARRIdo de Boggs (1953) pág. 285; CoRNEJo (1948) pág. 300; Espinosa (1915) págs. 345-346.

57 Queda mucho por hacer respecto a la adivinanza popular medieval hispánica, cuyo estudio se complica por la coexistencia y compenetración de la adivinanza literaria. Sobre esta, como era de esperar, hay importantes observaciones en TAYLOR (1948) págs. 100-109. Sobre la adivinanza medieval y renacentista véanse también A. D. Deyermond, «Motivos y técnica estructural en el Libro de Apolonio», Filología (Buenos Aires) 13 (1968-1969) págs. 121-149: pág. 137; J. Pérez VIDAL, «Dos notas al libro de Apolonio», Revista de Dialectología y Tradiciones Populares 9 (1953) págs. 89-94; Olivares Figueroa (1948); KarlLudwig Selig, «Spanish Proverbs and the Comedia de Amán y Mordochay», Proverbium 15 (1970) pág. 114. Es excelente el artículo de Harriet Goldberg, «Riddles and Enigmas in Medieval Castilian Literature», Romance Philology 36 (1982-1983) págs. 209-221.

58 Apud Justo de SANCHA (ed.), Romancero y cancionero sagrados (Madrid 1950 = BAAEE vol. 35) pág. 172 (núm. 414). El poema a lo divino de Ledesma pone la 
Luria observa que la frase «Une coze, coze muy maraviyoze ...» se usa como "general heading for all "indivines" (pág. 88 y nota). La forma completa de su texto sería, por lo tanto, una coplita anisosilábica asonantada en ó $-e(=\delta$ - $a)$ : «Une coze, coze muy marviyoze: / Al ag̉ue 'stá, no si moje», como los demás ejemplos hispánicos aquí citados. Si traemos a colación el siguiente texto de Nuevo México, no podemos por menos de convencernos del origen hispánico de nuestro enigma sefardí:

¡Qué cosa tan maravillosa!

Que entra al mar y no se moja.

(El sol) ${ }^{59}$.

Como también hemos hecho respecto a los enigmas de $\mathrm{M}$. Azuz (1945), resulta interesante presentar un recuento -tentativo por cierto- de los orígenes probables de nuestras adivinanzas. En el caso de los nueve enigmas de Azuz, cuatro habían de ser de origen hispánico y tres de origen oriental, quedando uno dudoso y uno desconocido. En lo que se refiere a la colección de Milwitzky llegamos a resultados no muy diferentes: tres de estas adivinanzas de Estambul son indudablemente hispánico-peninsulares: 1 aldabilla, 5 cubo (también en Azuz) y 9 sol. También 3 caballo es probablemente hispánico, aunque es menos segura la atribución que en los otros tres casos. La coleccioncilla contiene dos adivinanzas obviamente orientales, presentes ambas también en la colección de Azuz: 6 oreja, del turco, y 8 rábano, probablemente del griego. Quedan dos casos imposibles de precisar: 4 caballo y arreos y 7 pluma, mientras que el 2 asno permanece por ahora desconocido.

Dada la extensión limitadísima del corpus, resulta muy arriesgado llegar a conclusiones de largo alcance. Con todo, creemos que las dos breves colecciones, la de Azuz y la de

adivinanza tradicional en relación con la «virginidad de Nuestra Señora», motivo que, según la bien razonada exposición de TAYLOR (1936), puede relacionarse con la solución «sol» desde una fecha muy temprana, si no desde su origen (págs. 89-90). Sobre el texto de Ledesma véanse también Rodríguez MARÍn (1951) pág. 310 nota 3 (del núm. 252); Olivares Figueroa (1948) pág. 93.

59 Campa (1937) 146; el propio Campa 89 y Espinosa (1915) 120 traen textos parecidos referentes a la sombra. Sobre los comienzos formulísticos de las adivinanzas en la tradición hispánica véanse Moya (1955) págs. 24-25, y MELo (1976) pág. 10, aunque se podrían citar bastantes más ejemplos. 
Milwitzky, tienden a apoyar nuestra tesis del eclecticismo de la tradición judeoespañola ${ }^{60}$.

\section{BiBLIOGRAFÍA CITADA ABREVIADAMENTE}

Aввотт, G. F., Macedonian Folklore (Cambridge Ingl. 1903).

Almeida Oliveira, S., "Cem adivinhas populares», Revista do Arquivo Municipal (São Paulo) 6:66 [1940] págs. 59-76.

Amades, Joan, Folklore de Catalunya: II Cançoner: Cançons, refranys, endevinalles (Barcelona 1951).

Andrade, M. J., Folk-lore from the Dominican Repubic (Nueva York 1930).

Argenti, Ph. P., y H. J. Rose, The Folklore of Chios, 2 vols. (Cambridge Ingl. 1949).

Azuz, Menahem, "Hidot / Enigmas», Hed ha-Mizrah / Echo of the Orient (Jerusalén) 3:36 (26 en. 45) pág. 7; 3:40-41 (25 fb. 45) pág. 12.

Bafeiados, Balasia G., «'Éthe kaì 'éthima Sōzopoleōs», Laografía 29 (1974) págs. 115-226.

Baratta, María de, Cuzcatlán típico: Ensayo sobre etnofonía de El Salvador, 2 vols. (San Salvador 1952).

BAşGöz, I., y A. TIETZE, Bilmece: A Corpus of Turkish Riddles (Berkeley - Los Angeles 1973).

Beutler, Gisela, «Adivinanzas de tradición oral en Norte de Santander (Colombia)», Thesaurus 18 (1963) págs. 404-427.

BoGGS, R. S., y E. GARRIDO DE BOGGS, "Unas categorías de adivinanzas ilustradas con ejemplos dominicanos», en Antología ibérica y americana del folklore, ed. Félix Coluccio (Buenos Aires 1953) págs. 285-290.

BRIZ = F. PELAY y BRIZ, Endevinallas populars catalanas (Barcelona 1882).

Caballero, Fernán (= Cecilia Böhl de Faber), «Adivinanzas infantiles», Obras (Madrid 1961) vol. V págs. 234-246.

Campa, A. L., Sayings and Riddles in New Mexico (Albuquerque 1937).

Carrizo, Juan Alfonso, Cancionero popular de La Rioja, 3 vols. (Buenos Aires 1942).

COLÁN SECAS, Hermógenes, «Adivinanzas de Huaral», Revista del Instituto Nacional de la Tradición (Buenos Aires) 1 (1948) págs. 138-147.

${ }^{60}$ Queremos dar las gracias más cumplidas a nuestro entrañable amigo Iacob M. Hassán. Colaborador más que editor en este estudio, lo ha mejorado en todo sentido por su dominio sin par del campo de los estudios sefardies, tanto en sus materias primas como en su extensa bibliografía crítica. 
CORnEJo, J., «Adivinanzas ecuatorianas», Revista del Instituto Nacional de la Tradición 1 (1948) págs. 295-356.

Demófilo (= Antonio Machado y Álvarez), Colección de enigmas y adivinanzas (Sevilla 1880).

DIETERICH, K., «Neugriechische Rätseldichtung», Zeitschrift des Vereins für Volkskunde 14 (1904) págs. 87-104.

DIETERICH, K., Sprache und Volksüberlieferungen der südlichen Sporaden im Vergleich mit denen der übrigen Inseln des Ägäischen Meeres (Viena 1908).

Dufource, L., "Noticias relacionadas con el folklore de Lebu», Anales de la Facultad de Filosofía y Educación (Universidad de Chile): Sección de Filología 3 (1941-1943) págs. 225-294.

ElneCAvÉ, D., «Folklore de los sefardíes de Turquía: II», Sefarad 23 (1963) págs. 325-334.

Espinosa, Aurelio M., «New-Mexican Spanish Folk-Lore: IX Riddles», Journal of American Folklore 28 (1915) págs. 319-352.

FLORES, E., «Adivinanzas corrientes en Chile», Revista de Folklore Chileno 2 (1911) págs. 137-334.

Galante, Abraham, Appendice à l'Histoire des Juifs de Rhodes, Chio, Cos, etc. (Estambul 1948).

Garrido de Boggs, Edna, Folklore infantil de Santo Domingo (Madrid 1955).

GiACOBETTI, A., Recueil d'enigmes arabes populaires (Argel 1916).

Giménez Cabrera, Leopoldo, «Adivinanzas oídas en La Habana», Archivos del Folklore Cubano (La Habana) 2 (1926-1927) págs. 329-336.

Hamamizade, Ihsan, Bilmeceler (Estambul 1930).

IoAnNIDEs; S., Historia kai statistiké Trapezoüntos (Constantinopla 1870).

JiJena SÁnchez, Rafael, Adivina adivinador (Buenos Aires 1948).

KowAlski, Tadeusz, «Türkische Volksrätsel aus Kleinasien», Archiv Orientální (Praga) 4 (1932a) págs. 295-324.

KowALSKI, T., «Türkische Volksrätsel aus Nordbulgarien», en Festschrift Georg Jacob (Leipzig 1932b) págs. 128-145.

Lehmann-Nitsche, R., Adivinanzas rioplatenses (Buenos Aires 1911).

Luria, Max A., "A Study of the Monastir Dialect of Judeo-Spanish Based on Oral Material Collected in Monastir, Yugoslavia», Revue Hispanique (París) 79 (1930) págs. 323-583; citamos por la edición como libro (Nueva York 1930).

Mason, J. Alden, Folklore puertorriqueño: I Adivinanzas (San Juan 1960).

Massip, Salvador, «Adivinanzas corrientes en Cuba», Archivos del Folklore Cubano 1 (1924-1925) págs. 305-339. 
Melo, J. M. de, Enigmas populares (Río de Janeiro 1950).

Melo, J. M. de, Enigmas populares (Río de Janeiro 1976).

Melo, V. de, Adivinhas (Natal 1948).

MenA, Vicente, "Adivina adivinador", Antologia del folklore ecuatoriano, ed. Paulo de Carvalho-Neto (Cuenca Ec. 1970) vol. II págs. $15-28$.

Milá y Fontanals, M., «Énigmes populaires catalanes», Revue des Langues Romanes (Montpellier) $2^{\mathrm{a}}$ serie $2=10$ (1876) págs. 22-27.

MOROTE BEST, E., «Nuestras 100 primeras adivinanzas», Tradición (Cuzco) 1:2 (1950) págs. 75-100.

MoYA, I., Adivinanzas tradicionales (Buenos Aires 1955).

Novakovic, S., Srpske narodne zagonetke (Belgrado - Panchevo 1877).

ÖGEL, B., «Riddles from Erzurum», Journal of American Folklore 63 (1950) págs. 413-424

Olivares FigueroA, R., «Pedagogía del folklore: Proyecciones de la adivinanza», Educación, Revista para el Magisterio (Caracas) 9:53 (1948) págs. 92-97.

PAPACHRISTODOULOS, P., «Aìnígmata thrạkiká ('Ek Saránta 'Ekklēsiõn)», Laografia 2 (1910) págs. 193-194.

PAREDES CANDIA, A., Literatura folklórica (Recogida de la tradición oral boliviana) (La Paz 1953).

Paredes Candia, A., Adivinanzas de doble sentido (Folklore secreto) (La Paz 1976).

PARsons, E. C., Folk-lore from the Cape Verde Islands, 2 vols. (Cambridge Mass. - Nueva York 1923).

Pedersen, H., Zur albanesischen Volkskunde (Copenhage 1898).

Pino Sepúlveda, O., «La forma de las adivinanzas chilenas», Archivos del Folklore Chileno 9 (1971) págs. 25-41.

Pires, A. Th., «Adivinhas portuguezas recolhidas da tradição oral na província do Alemtejo», Archivio per lo Studio delle Tradizioni Popolari 3 (1884) págs. 113-140, 241-250.

Pires, A. Th., "Adivinhas portuguezas (Recolhidas na província do Douro)», Revista Lusitana (Oporto) 1 (1887-1889) págs. 263-266.

PIREs, A. Th., «Adivinhas portuguezas (Recolhidas da tradição oral na província do Douro)», Archivio per lo Studio delle Tradizioni Popolari 7 (1888) págs. 246-248.

Plath, Oreste (= Octavio Müller-Leiva), Folklore chileno, $3^{\mathbf{a}}$ ed. (Santiago 1969).

Politis, N. G., et al., «Dēmōdè aìnígmata», Neoellēnikà 'Análekta 1:4 (1871) págs. 193-256.

Ramírez de ARellano, Rafael, Folklore portorriqueño: Cuentos y adivinanzas (Madrid 1926).

RECINOS, A., «Adivinanzas recogidas en Guatemala», Journal of American Folklore 31 (1918) págs. 544-549. 
Reichel-Dolmatoff, Gerardo y Alicia, «La literatura oral de una aldea colombiana», Divulgaciones Etnológicas (Barranquilla) 5 (1956) págs. $5-125$.

RivadeneIRA, Ester, «Folklore de la provincia de Bio-Bío», Revista Chilena de Historia y Geografía (Santiago) 87:95 (1939) págs. 95-161.

Robe, Stanley L., Hispanic Riddles from Panama, Collected from Oral Tradition (Berkeley - Los Angeles 1963).

Rodríguez Marín, Francisco, Cantos populares españoles, 5 vols. (Sevilla 1882-1883; reed. Madrid [1951]).

Rolland, E., Divinettes ou énigmes populaires de la France [París 1877].

Soustelle, G. y J., Folklore chilien (París [1938]).

STATHES, S. E., «Kythëraïkà aìnígmata», Laografía 2 (1910) págs. 330370.

TAYlor, Archer, "What Goes Through Water and is Not Wet?», Modern Language Notes 51 (1936) págs. 86-90.

TAYLOR, A., «Problems in the Study of Riddles», Southern Folklore Quarterly 2 (1938) págs. 1-9.

TAYLOR, A., The Literary Riddle before 1600 (Berkeley - Los Angeles 1948).

TAYLOR, A., English Riddles from Oral Tradition (Berkeley - Los Angeles 1951).

TsCHIEDEL, J., «Italienische Volksrätsel», Zeitschrift des Vereins für Volkskunde 6 (1896) págs. 276-283.

VAlle, C., «Tradiçōes populares de Vila Nova de Gaia: Adivinhas Tradicionais", Revista de Etnografia (Oporto) 7 (1966) págs. 151-175.

Velásouez, R., «Adivinanzas del Alto y Bajo Chocó», Revista Colombiana de Folclor 2:5 (1960) págs. 101-129.

Villafuerte, C., Adivinanzas recogidas en la Provincia de Catamarca (Buenos Aires 1975).

Zervopoulou, A. P., «Aìnígmata 'ex 'Arkadías», Laografía 24 (1966) págs. 447-455.

(Entregado para Estudios Sefardies en 1985)

\section{Adenda (1998): Suplemento a las notas}

Nota 2: Para el estudio de los cuentos tradicionales sefardíes, ahora poseemos un indispensable instrumento de trabajo: Reginetta Haboucha, Types and Motifs of the Judeo-Spanish Folktales (Nueva York 1992), donde en págs. 20-22, 436-439 y 534-538 se analizan exhaustivamente los cuentos citados. Los Castigos e documentos ahora pueden consultarse en una nueva edición (en microficha), basada en un Ms. diferente del que siguió Rey en su edición de 1952: John M. ZeMKE (ed.), Text and Concordances of Escorial MS. Z.III.4: "Castigos e documentos» 
and "Libro del consejo e de los consejeros» (Madison, Wisconsin 1992). Para más datos sobre elementos balcánico-orientales en la literatura oral sefardí, véase ahora el artículo de S. G. Armistead, «Eyebrows like Leeches: Balkan Elements in a Judeo-Spanish Song», La Corónica 24:2 (1996) págs. 18-30.

Nota 3: En el estudio de la lírica se han realizado grandes progresos desde que escribimos el presente artículo, que no es este el lugar de reseñar. Hay que tener en cuenta, para las endechas: Paloma Diaz-MAs, Temas y tópicos en la poesía luctuosa sefardí (tesis doctoral: Univ. Complutense, Madrid 1981); para influencias postdiaspóricas: José M. PEDrosa, Fuentes y correspondencias hispánicas del cancionero sefardí de Oriente: Estudios comparativos (tesis doctoral: UNED, Madrid 1993); para varios géneros líricos: Paloma Diaz-Mas, Poesía oral sefardí (Ferrol 1994), y las contribuciones de José M. Pedrosa y Elena Romero a Alberto Hemsi, Cancionero sefardí, ed. Edwin Seroussı et al. (Jerusalén 1995). Para las coplas son indispensables Elena Romero, Coplas sefardies: Primera selección (Córdoba 1988), y Elena Romero et al., Bibliografía analítica de ediciones de coplas sefardíes (Madrid 1992).

Nota 8: Para amplios datos bibliográficos sobre las adivinanzas hispánicas véanse ahora, además del artículo en el Homenaje a Alvaro Galmés de Fuentes (citado supra nota 39), mis siguientes publicaciones: «Más adivinanzas españolas de Luisiana», en Homenaje a Alonso Zamora Vicente, 2 vols. (Madrid 1989) vol. II págs. 25-38, y The Spanish Tradition in Louisiana: "Isleño» Folkliterature (Newark, Delaware 1992) págs. 109-122. Sobre la supuesta falta de adivinanzas en la tradición judía, Dan Ben-Amos me ofrece las siguientes referencias cruciales: Dan PAGIS en A Secret Sealed: Hebrew Baroque Emblem Riddles from Italy and Holland (Jerusalem 1986) (en hebreo) pág. 20 nota 21 aduce una serie de precisiones (con extensa bibliografía, págs. 263-270) destinadas a enmendar la perspectiva demasiado restringida de TAYLOR (1951). Para adivinanzas en yidish, nótese la colección pionera de Shloyme Bastomski, Yidishe folksretenishn (Adivinanzas populares en yidish) (Vilna 1917), así como los estudios de Jennifer Dowling, «Riddles and Riddle Parodies: Shloyme Bastomski's Yidishe folksretenishn», en History of Yiddish Studies: Winter Studies in Yiddish, ed. Dov-Ber KERLER (Filadelfia 1991) vol. III págs. 81-92, y de Rina LapIDUs, «The Metaphor in the Riddle Genre: Sub-Categories in the Yiddish Riddle», Chulyot: Journal of Yiddish Research 2 (1994) págs. 197-209 (en hebreo). Para adivinanzas judías en el siglo $X$ en al-Andalus véase Nehemya Aluny, «Ten Dunash ben Labrat's Riddles», Jewish Quarterly Review 36 (1945-1946) págs. 141-146. Además, para los siglos XI a XII, Bruce Rosenstock me recuerda el poema-adivinanza de Moisés ibn Ezra, «Holat ahabim» (T. CARMI, The Penguin Book of Hebrew Verse [Nueva York 1981] pág. 326); y Elena Romero me advierte el también poemaadivinanza de Salomón ibn Gabirol, «Leholat ahabá» (E. Romero [ed. y trad.], Selomó ibn Gabirol, Poesía secular [Madrid: Alfaguara, 1978] págs. 402-403 núm. 129). Para interesantes consideraciones teóricas sobre las adivinanzas en una perspectiva mundial, véase Galit Hasan-Rokem y David Shulman (eds.), Untying the Knot: On Riddles and other Enigmatic Modes (New York-Oxford 1996).

Nota 10: Para algunos Griffrätsel turcos, véase Archer TAYLOR y Wolfram Eberhard, «Turkish Riddles from the Taurus Mountains», Western Folklore 17 (1958) págs. 249-256 núms. 50, 53-57. 
Nota 16: Huelga decir que la oposición noche-día es frecuente en el lenguaje folk-literario: «Lo que de noche se faze, de día pareçe» (Marqués de Santillana apud E. S. O'KANE, Refranes y frases proverbiales españoles de la Edad Media [Madrid 1959] pág. 170); junto con otros varios ejemplos de origen sefardí: «La notche cazar, al día parir» (E. SAPORTA Y BEJA; Refranes de los judios sefardies [Barcelona 1978] pág. 140). Me acuerdo de la siguiente imprecación en yidish: «Er zol vern azoy vi a lamp: B'tug zol er hengen un b'nacht zol er brenen» 'Que se haga como una lámpara: De día colgando y de noche quemando' (de tradición oral).

Nota 22: Hay una versión española idéntica en Joaquín DiAz y Modesto Martín, Adivinanzas de Castilla y León (Valladolid 1995) núm. 173; compárese también esta otra cubana (expurgada seguramente): «Entre más gordo y pelúo mejor para sentarse (El caballo)" (Almudena MonTEs, Adivinanzas, trabalenguas, dicharachos, refranes cubanos [Madrid 1997] pág. 40).

Nota 27: Montes Adivinanzas recoge dos versiones variantes de Cuba (págs. 28, 29-30).

Nota 29: Véase ahora la excelente (y no expurgada) traducción de S. FanjuL: Al-Hamadhānī, Venturas y desventuras del pícaro Abū l-Fath de Alejandría (Maqāmāt) (Madrid 1988) págs. 114-117.

Nota 40: Para otro ejemplo turco, véase Achilleos S. Diamantaras, «Tourkikè̀e laografía», Laografía 3 (1911) págs. 227-236: pág. 233 núm. 7.

Nota 47: Nótese esta versión de El Salvador: «Colorado y no es clavel; / blanco como papel; / pica y pimienta no es (El rábano)» (Ciriaco Salvador AlvarenGa UlloA, 456 Adivinanzas [San Salvador 1990] núm. 325).

Nota 56: Téngase en cuenta también esta lectura cubana relativa a la sombra: «Un señorita muy enseñorada; / pasa por el agua y no se moja nada (La sombra)» (MonTes Adivinanzas pág. 33).

Nota 60: Ahora me incumbe no sólo volver a agradecer de todo corazón a Iacob M. Hassán sus valiosas indicaciones bibliográficas, sino también a Elena Romero su eficaz y erudita intervención editorial, así como a mis amigos Dan Ben-Amos, Manuel da Costa Fontes, Bruce Rosenstock, Susana Weich-Shahak y John M. Zemke su amable ayuda con varios problemas de bibliografía. Sobre el carácter ecléctico de la tradición «enigmática» sefardí, véase ahora también S. G. Armistead y J. H. Silverman, «Two Judeo-Spanish Riddles of Greek Origin», Laografía 33 (1982-1984) págs. 169-175. 


\section{RESUMEN}

De la abundante colección de literatura oral judeoespañola de los Balcanes, recogida en 1898-1899 por William Milwitzky en Yugoslavia, Rumanía, Bulgaria, Grecia y Turquía, se editan y se estudian nueve adivinanzas hasta ahora inéditas procedentes de Estambul, cuyas soluciones son el cerrojo (de la puerta) (1), el asno (2), el caballo (y sus arreos) (3-4), el cubo del pozo (5), la oreja (6a-6b), la pluma (7), el rábano (8) y el sol (9). Por lo que se refiere a su posible origen, cuatro de estas adivinanzas resultan ser hispánico-peninsulares $(1,5,9$; y posiblemente también 3 ), otras dos son obviamente de origen oriental $(6,8)$, en tanto que el origen de otras tres resulta imposible de precisar $(2,4,7)$. Pese a la limitadísima extensión del corpus, tiende a confirmar, según creemos, el carácter culturalmente ecléctico de la tradición «enigmática» judeoespañola, ya señalado en la exigua colección del rabino Menahem Azuz (vid. nota 6 supra).

\section{SUMMARY}

From the extensive collection of Eastern Judeo-Spanish oral literature, brought together by William Milwitzky, in Yugoslavia, Rumania, Bulgaria, Greece, and Turkey, in 1898-1899, nine previously unedited riddles from Istanbul are edited and studied in detail. Their solutions refer to the bolt (of a door) (1); the burro (2); the horse (and its harness) (3-4); the bucket (of a well) (5); the ear (6a-6b); the writing pen (7); the radish (8); the sun (9). In regard to their possible origins, four of these riddles have close peninsular analogues (1, 5, 9; possibly also 3 ); two others obviously originated in the Balkans $(6,8)$; while the origin of the other three cannot be determined $(2,4,7)$. Despite the limited number of riddles collected by Milwitzky, they would seem to confirm the tradition's culturally eclectic character, already noted in Rabbi Menahem Azuz's small collection (see note 6). 